\title{
Antecedents and Consequences of Consumer Satisfaction in the Context of Special Occasion at Trade Exhibitions and the Halal Business in Indonesia: A Method Based on Partial Least Squares (PLS) Path Modeling
}

\author{
Setiawan Zunan ${ }^{1, *}$ Purwoko ${ }^{2,}$ Setiawan Ari ${ }^{3}$ Sasongko, Agung Hari ${ }^{4}$, Pratiwi, Ratih ${ }^{5}$
} Adiyono $^{6}$

\author{
${ }^{1}$ Universitas Ahmad Dahlan, Indonesia \\ ${ }^{2}$ Universitas Ahmad Dahlan, Indonesia \\ ${ }^{3}$ Universitas Sarjanawiyata Tamansiswa, Indonesia \\ ${ }^{4}$ Universitas Bina Nusantara, Indonesia \\ ${ }^{5}$ Universitas Wachid Hasyim, Indonesia \\ ${ }^{6}$ STIT Ibnu Rusyd, Indonesia \\ *Corresponding author.Email: zunan.setiawan@mm.uad.ac.id.
}

\begin{abstract}
The analysis model is validated using structured equation modeling (PLS-SEM) on datasets of both local and international trade exhibition attendees and the Indonesian halal business. Along with examining the model, this study will incorporate consumer satisfaction to validate the perceived quality factors conclusions. It is highlighted the importance of examining the relationship between perceived quality, value perception, satisfaction, and loyalty. We received 262 completed questionnaires in total. The structural models and measurements were examined using a combination of partial most minor (PLS) and structural equation techniques (PLS-SEM). Our empirical investigation supports the conceptual framework hypothesis by demonstrating that quality, value perception, and satisfaction consistently positively and significantly affect behavioral intent.
\end{abstract}

Keywords: Quality, Perceived Value, Satisfaction, Loyalty

\section{INTRODUCTION}

While interest in refining special event marketing tactics continues to grow, scientific research in this area is lagging. Prior research has focused on the psychological factors influencing customer behavior during extraordinary events [1]. Additionally, one of the essential strategies for enhancing the competitive market position of special events is to cultivate long-term client connections. The intention chain study demonstrates a direct correlation between the quality and value of tourism services and tourist behavioral intents such as revisiting and positive advocacy. Yoon reveals that tourists assess the effectiveness of the activity and the presentation of the natural atmosphere during a special occasion, which affects post-visit perceptions [2].

\section{LITERATURE REVIEW}

\subsection{Theorem of Consumption Values}

Individuals attending conferences usually want benefits not directly related to features, experience, function, sociability, emotion, or cost, including easy access to products and speedy response to inquiries. According to the consuming theory approach, consumer decisions result from a mix of functional and emotional assessments made in reaction to unique experiences [3]. The participants' social, economic, and emotional qualities affect their perceived value perception. In 
Indonesia, the perceived importance of essential things for fair exhibitions and halal business is critical for developing lasting customer relations [4].

\subsection{Special Occasion}

A greater degree of extraordinary events is increased by improving client satisfaction by increasing the perceived value of the experience, and they are more likely to return next time, which promotes positive wordof-mouth promotion [5]. Additionally, behavioral goals, such as return visits, continue to be crucial for successfully managing occurrences. Special organizers ought to be aware of the primary factors affecting, i.e., pre-experience evaluation, to foster long-term partnerships that result in repeat visits [6]. As such, this study established a hypothesis about the relationship between the attractiveness of special occasion and their effect on consumer satisfaction, perceived value, and intention.

\subsection{Perceived Quality}

Even if the quality of a particular performance increases, it is likely to boost an individual's value through substituting material sacrifices for perceived emotional qualities and projected benefits, such as the social ties formed. Yoon argues that the perceived value for extraordinary events rises proportionally to their perceived quality [2]. Thus, high-quality special events will make participants feel like they are making a significant sacrifice, and their value will ultimately be more accurately assessed.

\subsection{Perceived value}

Perceived Value at special events provides insight into consumer perceptions, which is crucial in the service sector, as maintaining a competitive edge is one of many businesses' primary objectives [7]. Consumer perceptions of value have become an integral part of the service marketing philosophy [8]. Prior work portrayed perceived value as a dynamic construct impacted by prior experience and events occurring during and after use [9].

Prior research examined the concept of perceived value to obtain a better understanding of how customers behave in various situations, including those involving brands, services, hospitality, and tourism [10]. Prior empirical research has concentrated on perceived value as a post-consumer evaluation of the tourism experience and its association with future objectives. Numerous scholars have examined the perceived worth of tourism, most notably in the context of uncommon occurrences. Their adventure tourism study discovered that five value elements (functional, monetary, emotional, social, and novelty) had a favorable effect on tourists' intents. The study discovered that hedonic values provide a more comprehensive explanation for festivals and special events than utilitarian values [11].

\subsection{Behavioral Intention}

Individuals' behavioral intention has developed into a critical component of management's (or organizer's) ability to comprehend consumer behavior (or tourists). Behavioral intentions manifest in various ways, including purchase intent, word-of-mouth marketing, and loyalty. Behavioral intents have been characterized as favorable or unfavorable [12]. All of these are examples of desirable behavioral intents. Loyalty, the willingness to pay a more fantastic price, and the intention to switch are all examples of desired behavioral intentions.

On the other hand, Undesired intents are buyer or tourist criticisms, which may take the form of verbal, personal, or third-party comments. Furthermore, consumer loyalty is typically associated with behavioral objectives. Furthermore, it is separated into two categories: behavioral variables and attitude components [13]

\section{RELATIONSHIPS BETWEEN VARIABLES}

Since 2019, exhibitions and the halal business have examined unique events focused on halal food and beverages, halal tourism, cosmetics, and pharmaceuticals. Even during the 2020 pandemic, special events focused on 11 topics, such as halal food and beverages, halal tourism, cosmetics, and pharmaceuticals, can be permitted. Halal certification, Islamic clothing, Islamic education, sharia finance, and sharia real estate are just a few of the topics discussedIndonesia's status as the world's largest Muslim-majority country and the largest market for halal products.

As a result, Indonesia is well-positioned to become a regional, if not global, the hub for halal products. A study was done to assess the concept by accumulating data to formulate the predicted relationship. Consumers who organized big occasions at trade exhibitions and in the halal industry were surveyed. This analysis focuses on the domestic market for a variety of reasons. Most tourism revenue is earned by unique visitors and tourist services targeted at domestic travel [14].

From a conceptual point of view, this is essential to consider the complexities of domestic consumer behavior, as their opinions frequently differ from those of overseas consumers [15]. Indonesia's home market is vital. The objective of this research is to use a conceptual relationship model to create the following hypotheses:

H1. Perceived quality has a significant and positive relationship with social value.

H2. Perceived quality has a significant and positive relationship economic value. 
H3. Perceived quality has a significant and positive relationship with emotional value.

H4. Social value has a significant and positive relationship with customer satisfaction.

H5. Economic value has a significant and positive relationship with customer satisfaction.

H6. Emotional value has a significant and positive relationship with customer satisfaction.

H7. Customer satisfaction has a significant and positive relationship with behavioral intentions.

\section{METHODOLOGICAL APPROACH}

\subsection{Research Setting}

HIEX (Halal Indonesia Expo) is returning to address the challenges confronting Indonesia's halal industry, which has enormous potential and is proliferating. A total of 262 legitimate and complete questionnaires were collected.

\subsection{Measurement}

Several measures frequently used in marketing literature, special occasions, and tourism provide extra information on the items used to quantify the construct of interest-three adaptations from Akhoondnejad [17]. Determine perceived value; eleven items are used from the previous study [18]. This dimension consists of three sub-dimensions: social (three items), financial (four items), and emotional (one item) (four items). All value questions were derived from a prior study [19] and were used to ascertain participants' behavioral intentions regarding the event. This component explored the factors that influence individuals' behavioral intentions for future specials in the context of Indonesian special occasions for trade fairs and the halal business. The survey data were analyzed using PLS-SEM. PLS-SEM is a well-suited statistical technique for research with a limited sample size [20]

Additionally, it is more suitable for predictive connection analysis than confirmatory relationship analysis, such as anticipating the determinants of behavioral intents for extraordinary events. Satisfaction research development begins with establishing a satisfaction research database via the creation of the watase. web. id application platform. This database comprises customer satisfaction surveys conducted in a variety of circumstances. The following is an example of a database view:

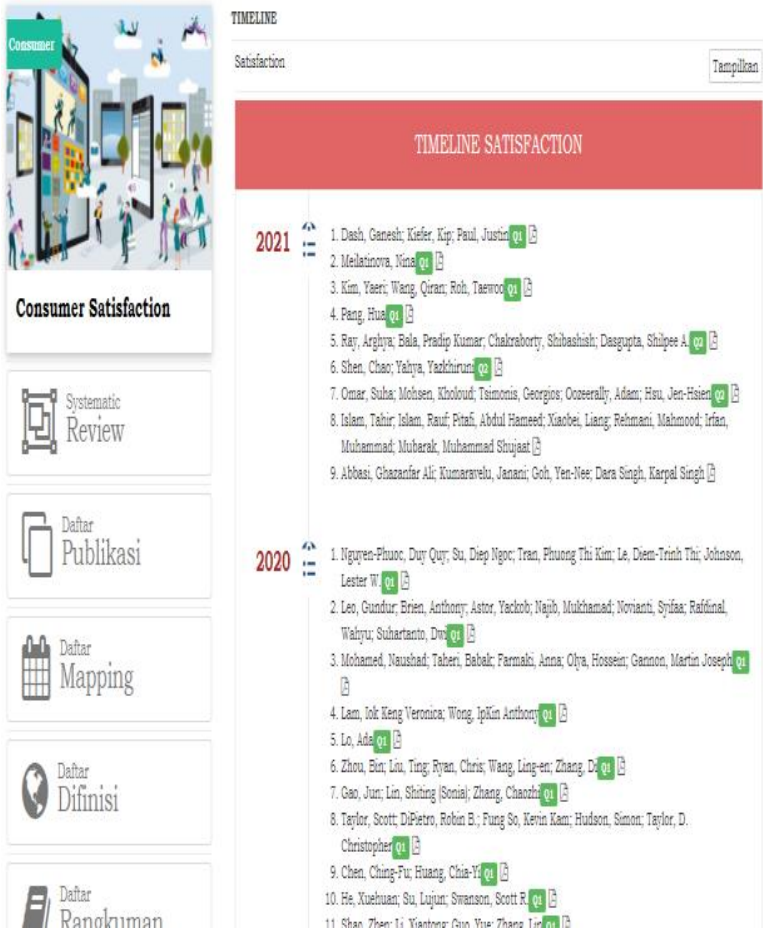

Source: watase.web.id

Figure 1 Database View

The study model for this study was created utilizing watase.web.id. The mapping process is described in the table:

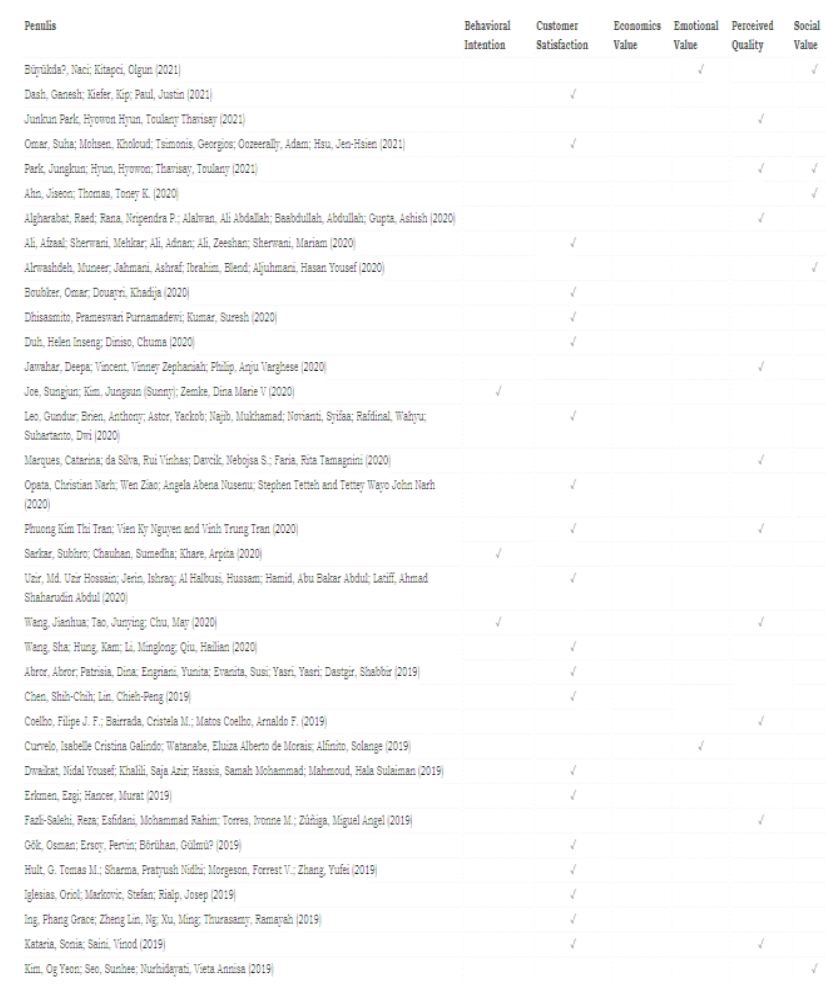

Source: watase.web.id.

Figure 2 The Mapping Process 


\subsection{Modeling of Research Concept}

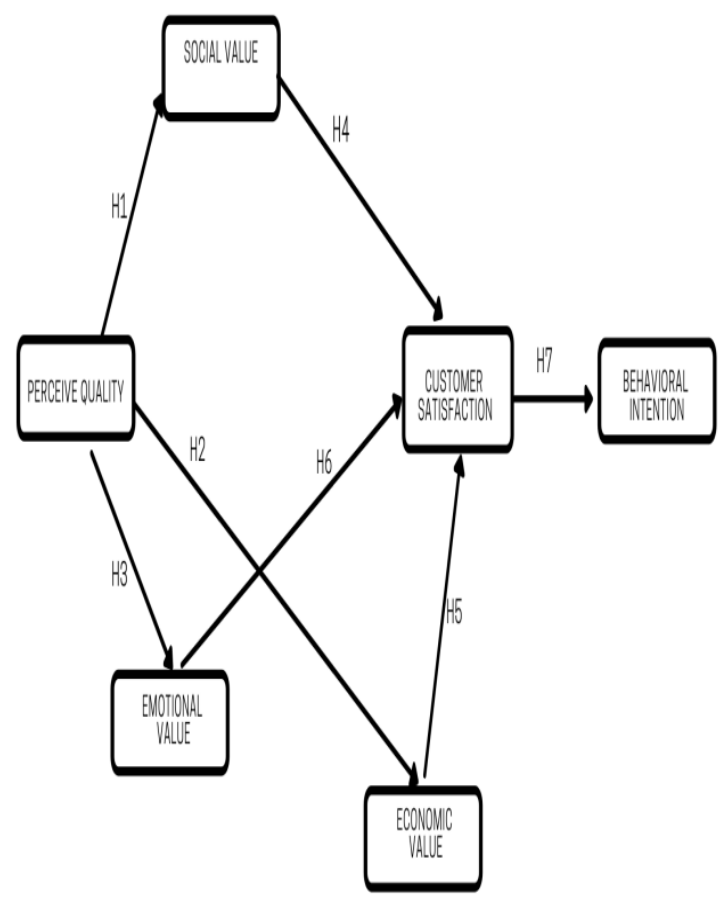

Figure 3 Modeling of Research Concept

\section{RESULT}

\subsection{Measurement Validation}

These samples were processed to PLS-SEM analysis using the SMART PLS tool version 3.3.2. Coherence within All three aspects of the testing process is reliability, convergent, and discriminant validity. Cronbach Alpha was used to determine the internal consistency of the reliability test results. The following table summarizes the results of the data analysis:

Table 1 Internal Consistency Reliability

\begin{tabular}{|c|c|c|}
\hline Variable & $\begin{array}{c}\text { Cronbach } \\
\text { Alpha }\end{array}$ & Test result \\
\hline Perceived Quality & 0.862 & Excellent \\
\hline $\begin{array}{c}\text { Customer } \\
\text { Satisfaction }\end{array}$ & 0.848 & Excellent \\
\hline $\begin{array}{c}\text { Behavioral Intention } \\
\text { Economic } \\
\text { Value }\end{array}$ & 0.885 & Excellent \\
\hline $\begin{array}{c}\text { Emotional } \\
\text { Value }\end{array}$ & 0.849 & Excellent \\
\hline $\begin{array}{c}\text { Social Value } \\
\text { Excellent }\end{array}$ \\
\hline
\end{tabular}

Source: Data Compiled in 2021

The reliability values are higher than 0.7 , as shown by the results mentioned above. Hair accepts Cronbach alpha values of more than 0.70 [21]. Thus, all variables satisfy the reliability analysis for logical consistency when aggregated. Convergent validity is calculated by evaluating the Indicators Reliability (The outside Loading) value to an AVE value (Average Variance Extracted). According to Hair, a typical outer loading value of 0.70 or higher is considered good, and a classical AVE value of 0.50 is considered highly good [21]. The convergent validity test results are summarized in the following table:

Table 2 The Convergent Validity Analysis

\begin{tabular}{|c|c|c|c|c|c|}
\hline Construct & Indicator & $\begin{array}{c}\text { Factor } \\
\text { Loading }\end{array}$ & CR & AVE & Status \\
\hline \multirow{3}{*}{$\begin{array}{l}\text { Perceive } \\
\text { Quality }\end{array}$} & KL11 & 0.869 & \multirow[t]{3}{*}{0.916} & \multirow[t]{3}{*}{0.784} & \multirow{3}{*}{$\begin{array}{l}\text { Very } \\
\text { good }\end{array}$} \\
\hline & KL12 & 0.912 & & & \\
\hline & KL13 & 0.874 & & & \\
\hline \multirow[t]{3}{*}{ Satisfaction } & KP14 & 0.883 & \multirow[t]{3}{*}{0.908} & \multirow[t]{3}{*}{0.767} & \multirow{3}{*}{$\begin{array}{l}\text { Very } \\
\text { good }\end{array}$} \\
\hline & KP15 & 0.864 & & & \\
\hline & KP16 & 0.88 & & & \\
\hline \multirow{4}{*}{$\begin{array}{l}\text { Economic } \\
\text { Value }\end{array}$} & NEK4 & 0.827 & \multirow[t]{4}{*}{0.899} & \multirow[t]{4}{*}{0.689} & \multirow{4}{*}{$\begin{array}{l}\text { Very } \\
\text { good }\end{array}$} \\
\hline & NEK5 & 0.828 & & & \\
\hline & NEK6 & 0.789 & & & \\
\hline & NEK7 & 0.875 & & & \\
\hline \multirow{3}{*}{$\begin{array}{l}\text { Emotional } \\
\text { Value }\end{array}$} & NES8 & 0.791 & \multirow[t]{3}{*}{0.896} & \multirow[t]{3}{*}{0.742} & \multirow{3}{*}{$\begin{array}{l}\text { Very } \\
\text { good }\end{array}$} \\
\hline & NES9 & 0.889 & & & \\
\hline & NES10 & 0.900 & & & \\
\hline \multirow[t]{3}{*}{ Social Value } & NS1 & 0.854 & \multirow[t]{3}{*}{0.895} & \multirow[t]{3}{*}{0.739} & \multirow{3}{*}{$\begin{array}{l}\text { Very } \\
\text { good }\end{array}$} \\
\hline & NS2 & 0.865 & & & \\
\hline & NS3 & 0.860 & & & \\
\hline \multirow{5}{*}{$\begin{array}{l}\text { Behavioral } \\
\text { Intention }\end{array}$} & NP17 & 0.805 & \multirow[t]{5}{*}{0.916} & \multirow[t]{5}{*}{0.687} & \multirow[t]{5}{*}{$\begin{array}{l}\text { Very } \\
\text { good }\end{array}$} \\
\hline & NP18 & 0.839 & & & \\
\hline & NP19 & 0.842 & & & \\
\hline & NP20 & 0.876 & & & \\
\hline & NP21 & 0.778 & & & \\
\hline
\end{tabular}

Source: Data Compiled in 2021

As indicated by the convergent validity test findings in the table above, the factor loading value is greater than 0.70 , and the AVE value is greater than 0.50. As a result, each variable, especially situational variables, has a high degree of convergent validity. The Fornell-Larcker criterion was utilized [21]. Increase the variable's crossloading value. The results of the discriminant validity test indicate that each variable fulfills the Fornell-Larcker criterion since it has the highest correlation score compared to other relationships. The following table summarizes the conclusions from research on discriminant validity testing: 
Table 3 The Convergent Validity Test

\begin{tabular}{|l|l|l|l|l|l|l|}
\hline Variable & $(1)$ & $(2)$ & $(3)$ & $(4)$ & $(5)$ & $(6)$ \\
\hline $\begin{array}{l}\text { Satisfaction } \\
(1)\end{array}$ & 0.876 & & & & & \\
\hline Quality (2) & 0.785 & 0.885 & & & & \\
\hline $\begin{array}{l}\text { Behavioral } \\
\text { Intention } \\
(3)\end{array}$ & 0.758 & 0.772 & 0.829 & & & \\
\hline $\begin{array}{l}\text { Economic } \\
\text { Value (4) }\end{array}$ & 0.761 & 0.816 & 0.811 & 0.830 & & \\
\hline $\begin{array}{l}\text { Emotional } \\
\text { Value (5) }\end{array}$ & 0.706 & 0.821 & 0.717 & 0.748 & 0.861 & \\
\hline $\begin{array}{l}\text { Social } \\
\text { Values (6) }\end{array}$ & 0.741 & 0.744 & 0.775 & 0.846 & 0.782 & 0.860 \\
\hline
\end{tabular}

Source: Data Processed 2021

\subsection{The Research Structural Model}

Based on the analyses of the observed variables, the structural equation model analysis is selected to check the hypothesis that has been stated previously. Accomplished by analyzing the significance of the hypothesized factors' relationship. The outcomes of the PLS-SEM analysis were as follows:

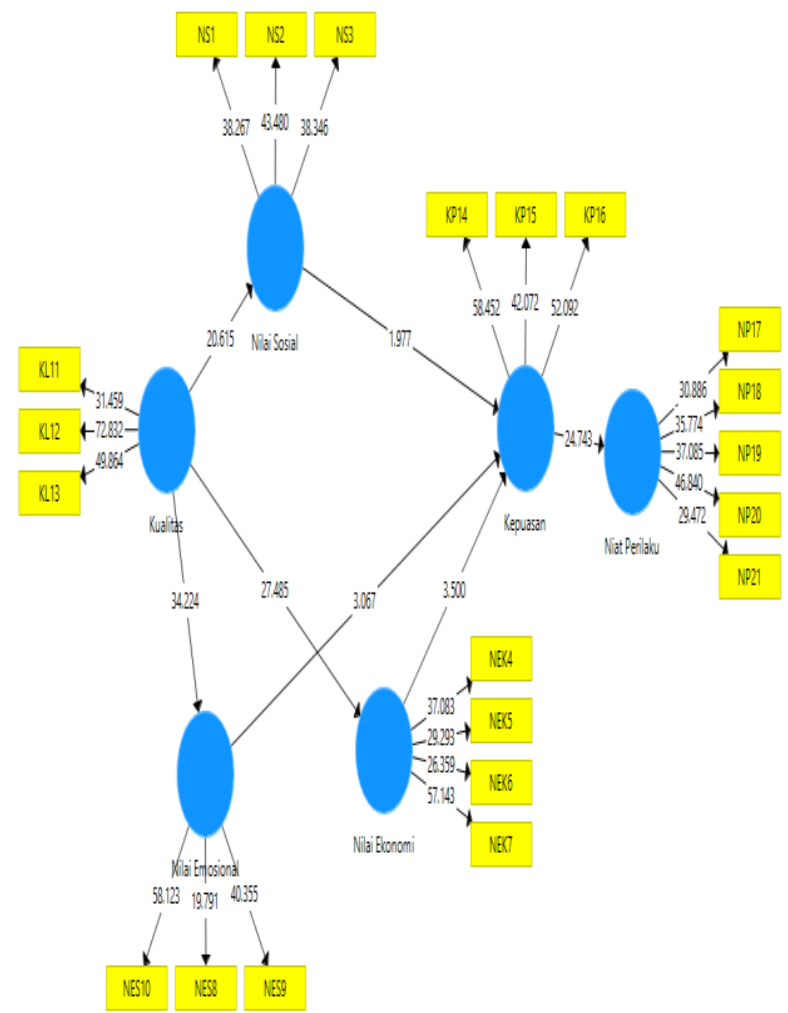

Source: SMARTPLS Visual Output from data processing Figure 4 Research Structural Model

\subsection{Hypothesis}

The following table describes the outcomes of complete hypothesis testing.

Table 4 The Result of Hypothesis

\begin{tabular}{|c|c|c|c|c|c|}
\hline Hypothesis & Beta & $\begin{array}{c}\text { Standard } \\
\text { Deviation }\end{array}$ & T test & $\begin{array}{c}\mathrm{P} \\
\text { Values }\end{array}$ & $\begin{array}{c}\text { Statu } \\
\mathrm{s}\end{array}$ \\
\hline $\begin{array}{c}\text { Quality } \rightarrow \\
\text { Economic } \\
\text { Value }\end{array}$ & 0.816 & 0.030 & 27,48 & 0.000 & $\begin{array}{c}\text { Signif } \\
\text { icant }\end{array}$ \\
\hline $\begin{array}{c}\text { Quality } \rightarrow \\
\text { Emotional } \\
\text { Value }\end{array}$ & 0.821 & 0.024 & 34,22 & 0.000 & $\begin{array}{c}\text { Signif } \\
\text { icant }\end{array}$ \\
\hline $\begin{array}{c}\text { Quality } \rightarrow \\
\text { Social } \\
\text { Value }\end{array}$ & 0.744 & 0.036 & 20,61 & 0.000 & $\begin{array}{c}\text { Signif } \\
\text { icant }\end{array}$ \\
\hline $\begin{array}{c}\text { Economic } \\
\text { Value } \rightarrow \\
\text { Satisfaction }\end{array}$ & 0.401 & 0.115 & 3,500 & 0.001 & $\begin{array}{c}\text { Signif } \\
\text { icant }\end{array}$ \\
\hline $\begin{array}{c}\text { Emotional } \\
\text { Value } \rightarrow \\
\text { Satisfaction }\end{array}$ & 0.237 & 0.077 & 3.067 & 0.002 & $\begin{array}{c}\text { Signif } \\
\text { icant }\end{array}$ \\
\hline $\begin{array}{c}\text { Social } \\
\text { Value } \rightarrow \\
\text { Satisfaction }\end{array}$ & 0.217 & 0.110 & 1.977 & 0.049 & $\begin{array}{c}\text { Signif } \\
\text { icant }\end{array}$ \\
\hline $\begin{array}{c}\text { Satisfaction } \\
\rightarrow \\
\text { Behavioral } \\
\text { Intention }\end{array}$ & 0.758 & 0.031 & 24,74 & 0.000 & $\begin{array}{c}\text { Signif } \\
\text { icant }\end{array}$ \\
\hline Source Data & & & 3 & & \\
\hline
\end{tabular}

Source: Data Processed 2021

The test findings indicating that quality affects economic value suggest a $t$ - statistic of 27.485 with a $p$ value of 0.000 . When a 95 percent confidence level is used, the significance level is 1.96. Because the t-test amount reaches 1.96 and the p-value is greater than 0.05 , the hypothesis is accepted. Economic value is inversely proportional to quality. The results of hypothesis testing indicate that the effect of quality on emotional well-being has a t-value of 34,224 and a p-value of 0.000 . The hypothesis is accepted because the t-test value is greater than the standard value. Quality is positively connected with emotional value. The t-test score for assessing the hypothesis that quality impacts social values was 20,615 with a p-value of 0.000 . Since the t-test value is greater than 1.96, the hypothesis is accepted. Qualitative characteristics have significant implications for social values.

The tests conducted on the hypothesis were a t-test value of 3.500 and a $p$-value of 0.001 , a t-test value of 3.067 and a p-value of 0.002 , and a t-test value of 1,977 and a p-value of 0.049 . The tests reveal that all three hypotheses are correct. Satisfaction is influenced by economic, emotional, and social values. With a t-test value of 24,743 and a p-value of 0.000 , the hypothesis 
testing results evaluate the effect of satisfaction on behavioral intentions. Because the t-test value is greater than 1.96, the hypothesis is accepted. Satisfaction has a beneficial effect on behavioral intentions.

\section{DISCUSSION}

Its outcome could very well be influenced by the fact that a variety of items and services are available at the special event, and those specific components of the special event's offering were developed based on attendees' impressions. As a result, participants may believe that the event's product and service offerings are pretty fair. Additionally, the findings imply that the direct effects of perceived program quality on customer satisfaction and behavioral intentions are consistent with social, economic, and emotional values. The results demonstrated that customer perceptions of their perceived quality as participants concerning event offerings could considerably predict consumer enjoyment and behavioral intentions toward special events. Simultaneously, perceived quality is critical for building perceived value across multiple dimensions, including social, economic, and emotional: the higher the perceived quality, the more committed the sequence of characters. This analysis suggested that perceived events quality had significant predictability for consumer satisfaction and behavioral intentions. It indicates the critical role of perceived quality in affecting consumer happiness and behavioral intentions, including consumer satisfaction with halal items and intention to return. These findings substantially contribute to the theoretical and managerial literature on service marketing, participant perceptions of value, and tourism behavior throughout special occasions.

\section{CONCLUSION}

The objective of this report was to evaluate the influence of perceived extraordinary event quality on customer valuation, satisfaction, and behavioral intentions. This study reveals that participants' assessments of the quality of special events significantly influence their behavioral intentions, both directly and indirectly. Both social and emotional values affect the outcome. The findings demonstrate that while consumer satisfaction and behavioral intentions directly affect a particular event's perceived value, they are not always the primary direct outcomes. The conceptual model also incorporates the direct effects of social, economic, and emotional value on consumer satisfaction and behavioral intentions by emphasizing the importance of facilitating perceived value. Additionally, the data indicate that social, economic, and emotional values appear to have a favorable effect on customer satisfaction and behavioral intentions.

\section{AUTHORS' CONTRIBUTIONS}

All writers contributed equally to developing the study methodology, language enhancements, and template adaptation in this article.

\section{ACKNOWLEDGMENTS}

The writer wishes to convey gratitude to numerous individuals, both family and acquaintances, who contributed to the successful completion of this paper.

\section{REFERENCES}

[1] Kirkup, N. and Sutherland, M. (2017), "Exploring the relationships between motivation, attachment and loyalty within sport event tourism", Current Issues in Tourism, Vol. 20 No. 1, pp. 7-14.

[2] Yoon, YS, Lee, JS and Lee, CK (2010), “Measuring festival quality and value affecting visitors satisfaction and loyalty using a structural approach", International Journal of Hospitality Management, Vol. 29 No. 2, pp. 335-342.

[3] Carlson, J., Rahman, MM, Taylor, A. and Voola, R. (2019), "Feel the VIBE: examining value-in-thebrand-page-experience and its impact on satisfaction and customer engagement behaviors in mobile social media", Journal of Retailing and Consumer Services, Vol. 46, pp. 149-162.

[4] Lee, JS, Lee, CK and Choi, Y. (2011), "Examining the role of emotional and functional values in festival evaluation", Journal of Travel Research, Vol. 50 No. 6, pp. 685-696.

[5] Wu, HC and Li, T. (2017), “A study of experiential quality, perceived value, heritage image, experiential satisfaction, and behavioral intentions for heritage tourists", Journal of Hospitality \& Tourism Research, Vol. 41 No. 8, pp. 904-944.

[6] Wong, J., Wu, HC and Cheng, CC (2015), "An empirical analysis of synthesizing the effects of festival quality, emotion, festival image and festival satisfaction on festival loyalty", A Case Study of Macau Food Festival, Vol. 17 No. 6, pp. 521-536.

[7] Kumar, V. and Reinartz, WJJOM (2016), Creating Enduring Customer Value, Vol. 80 No. 6, pp. 36-68.

[8] Plewa, C., Sweeney, JC and Michayluk, D. (2015), "Determining value in a complex service setting", Journal of Service Theory and Practice, Vol. 25 No. 5, pp. 568-591.

[9] Sanchez, J., Callarisa, L., Rodriguez, RM and Moliner, MA (2006), "Perceived value of the purchase of a tourism product", Tourism Management, Vol. 27 No. 3, pp. 394-409. 
[10] Williams, P. and Soutar, GN (2009), "VALUE, satisfaction and behavioral intentions IN an adventure tourism context", Annals of Tourism Research, Vol. 36 No. 3, pp. 413-438.

[11] Gursoy, D. Spangenberg, ER and Rutherford, DG (2006), "The hedonic and utilitarian dimensions of", Attitudes Toward Festivals, Vol. 30 No. 3, pp. 279294.

[12] Carlson, J., Rosenberger, PJ III and Rahman, MM (2015), "Cultivating group-oriented travel behavior to major events: assessing the importance of customer-perceived value, enduring event involvement and attitude towards the host destination", Journal of marketing management, Vol. 31 Nos. 9-10, pp. 1065-1089

[13] Wu, HC, Cheng, CC and Ai, CH (2018), "A study of experiential quality, experiential value, trust, corporate reputation, experiential satisfaction and behavioral intentions for cruise tourists: the case of Hong Kong”, Tourism Management, Vol . 66, pp. 200-220.

[14] Chen, CF and Chen, FS (2010), "Experience quality, perceived value, satisfaction and behavioral intentions of heritage tourists", Tourism Management, Vol. 31 No. 1, pp. 29-35.

[15] Caruana, A. and Ewing, MT (2010), "How corporate reputation, quality, and value influence online loyalty", Journal of Business Research, Vol. 63 No. 9, pp. 1103-1110.

[16] Moreno, FC, Prado-Gasco, V., Hervas, JC, NunezPomar, J. and Sanz, VA (2015), "Spectator emotions: effects on quality, satisfaction, value, and future intentions", Journal of Business Research, Vol. 68 No. 7, pp. 1445-1449.

[17] Akhoondnejad, A. (2016), “Tourist loyalty to a local cultural event: the case of Turkmen handicrafts festival", Tourism Management, Vol. 52, pp. 468477.

[18] Bradley, GL and Sparks, BA (2012), "Antecedents and consequences of consumer value", A Longitudinal Study of Timeshare Owners, Vol. 51 No. 2, pp. 191-204.

[19] Su, L., Swanson, SR and Chen, X. (2016), "The effects of perceived service quality on repurchase intentions and subjective well-being of Chinese tourists: the mediating role of relationship quality", Tourism Management, Vol. 52, pp. 82-95.

[20] Hair, J., Sarstedt, M., Hopkins, LG and Kuppelwieser, V. (2014), "Partial least squares structural equation modeling (PLS-SEM)", An
Emerging Tool in Business Research, Vol. 26 No. 2, pp. 106-121.

[21] Hair, JF, Sarstedt, M., Ringle, CM and Gudergan, SP (2017), Advanced Issues in Partial Least Squares Structural Equation Modeling, Sage Publications. 